The CLASSICAL QUARTERLY and CLASSICAL REVIEW are the organs of the Classical Association. The QUARTERLY is published in January, April, and October (double number); the REVIEW in February, May, July, September, November, and December.
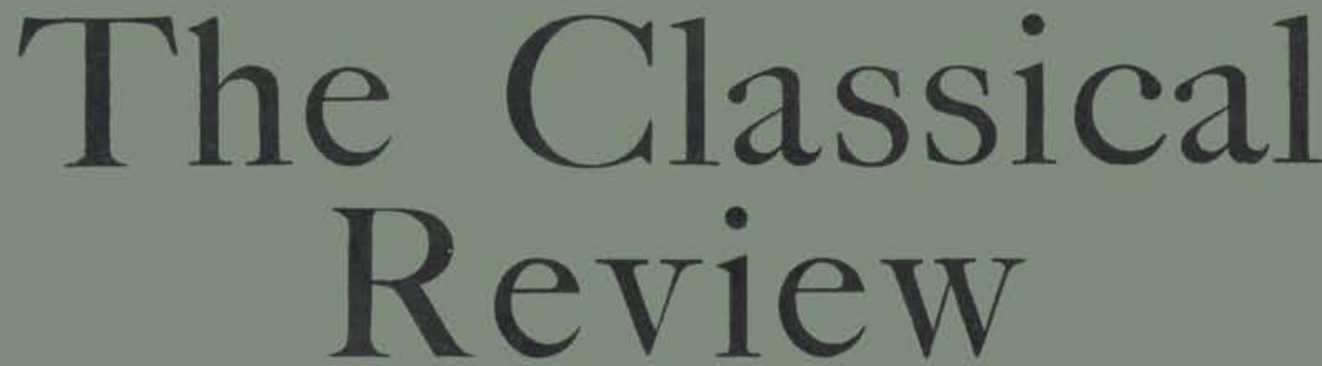

Editors $\left\{\begin{array}{l}\text { E. HARRISON, M.A., Trinity College, Cambridge. } \\ \text { Prof. W. M. CALDER, LL.D., 58, St. Albans Road, Edinburgh. }\end{array}\right.$

All correspondence should be addeessed to Prof. Cal.DER. Books for review should be sent to the Publisher

\title{
Board of Management:
}

Prof. D. S. ROBERTSON, M.A. (Chaiman), nepresenting thie Cambridge Philotogical Society

Prot, J. F. DOBSON, M.A.

Prof H. A. ORMEROD, M.A.

F. B. SANDBACH, M.A.
Prot. B. WILLIAMSON, M.A. (Hon. Treasurer). Fopresenting the CennAssociation.
E. A. BARBER, M.A. (Hon, Secretary),
,epresenting the Oxford philological iepresed
Society.

With the co-operation of Prof. E. B. RAND, Hanpard Utriversity, and Prof. W. J. WOODEOuSE, University of Syrincy.

Vol. XLVIII

\section{CONTENTS}

NOTES AND NEWS
THE AUTHORSHP OF THE "LEUCIPPIDFS

papyrus. J. A. Divison ..

Noth on PLato Charmides i53\%. $K$ W

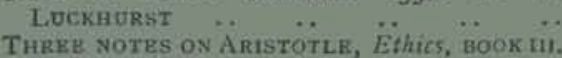

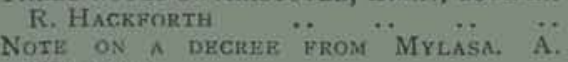

Wwo notes on Cícero, De Senectute. W. $\ddot{\text { S }}$ MAGUINNRSS $\ldots$.

NotEs oN LEWIS AND SHORT. R. $\ddot{\mathrm{L}}$. DUN-

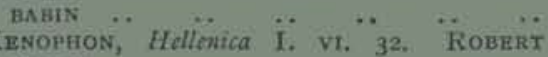
QUIRK ‥

ARISTOTLE, N.E. I. VI. I, $\operatorname{IOg} 6 \mathrm{~A}$ i4. H. RACKHAM ‥ …

A PAPYRUS CODEX AND AN BARLY DXAMPLE

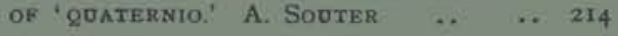

Reviews :

Staaten, Völker. Männer, aus der Gesehichte des Altertums (Kornemann). A. F. Gilles Corpus Vasorum Antiquorum. Yougoslavie, Fasc, I (Hoffiller). W. A. HEURTLEY

A Handbook of Greek Literalure (Rose): Griechische Literaturgeschichte, 2. Bd. (Geffcken). T. A. StNcLAIR ㅋ. $\ddot{\text { J }}$ Die Theogonie des Hesiodos (Schwenn). H. J.

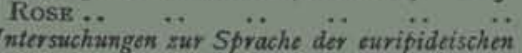
Lyrik (Breitenbach). J. D. DENisistoN
PAGR

205

205

207

208

210

211

212

$2 \mathrm{I} 4$

$2 \mathrm{I}_{4}$

275

216

217

219

220
Reviews (continued) :

Greck Particles (Denniston). W. L. Lorimer Aristoteles IIEPI HOHHTHKH之 (Gudeman).

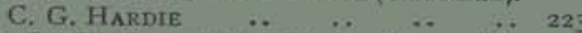

C. Lucilit Saturarum Reliquiae (Terzaghi).

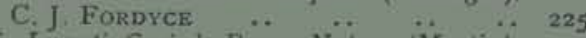

T. Lucreti Cari de Rerum Natura (Martin),

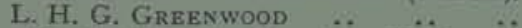
La Rivolta di Catilina (Amato). M. 'CARY

The Priapea and Ovid (Thomason). J. Wight DurF

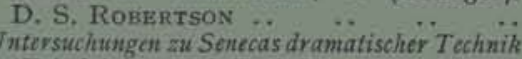
(Friedrich), W, F, J. KNIGHT .. ..

Studien zu den Anwalen des Tacitus (Eriksson). E. C. Marchant $\ldots$. Ptolemaios und Porphyrios über die Musik (Düring). J. F. MountFord .. ..

Claudion: Etudes stir sa Possie at son Temps and Invectives contre Eutrope (Fargues); Clatudian: The Rape of Proserpine in Eng. lish Verse (Pope). W. H. SEMPLE ‥ 232

Select Letters of St. Jerome, with an English translation (Wright). A. SOUTER ‥ 233

A History of Secular Latin Poetry in the Middle Ages (Raby). J. Wight Durp .. 236

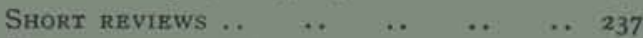

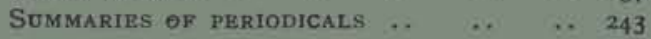
$\begin{array}{lllllll}\text { BOOKS RECEIVED } & \ldots & \ldots & \ldots & \ldots & 246\end{array}$ $\begin{array}{lllllllll}\text { INDEXES } & \ldots & \ldots & \ldots & \ldots & \ldots & \ldots & 247\end{array}$

LONDON: JOHN MURRAY, ALBEMARLE STREET, W. New YorK: G. E. STECHERT \& CO., 3I-33, EAST IOTH STREET. 


\section{THE}

\section{L A S S I C A L \\ R E V I E W \\ EDITED BY}

\section{E. HARRISON AND W. M. CALDER}

BOARD OF MANAGEMENT:

Prof. D. S. ROBERTSON, M.A. (Chairman)

Prof. H. Williamson, M.A. (Hon. Treasurer). $\quad$ E. A. BARBER, M.A. (Hon. Secretary).

Prof. J. F. DOBSON, M.A.; F. H. SANDBACH, M.A.;

Prof. H. A. ORMEROD, M.A., F.S.A.

With the co-operation of PRoF. E. K. RAND, Harvard University, and Prof. W. J. WOODHOUSE, University of Sydney.

\section{VOLUME XLVIII.}

PUBLISHED FOR THE CLASSICAL ASSOCIATION LONDON

JOHN MURRAY, ALBEMARLE STREET, W. NEW YORK

G. E. STECHERT \& CO., 3I-33, EAST IOTH STREET 


\section{TABLE OF CONTENTS}

No. 1 .

Notes and news

Simonides in the Theognidea. C. M. BowRA Notes on Aeschylus, Persae. I. J.C. LAwson Pindar and Korinna. H. J. Rose

Neryllinus. W. M. Ramsay

Cicero's conduct of the case pro Roscio. iv. B. SEDGWICK

The fate of the foedus $\dot{C}$ assianum. J. E. PownLi Aeschylus, Fragment 179 . A. Y. CAMPBeLL Pliny's Letters, X 87 3. W. S. Magdinness

Reviews :

Trade and Politics in Ancient Greece (Hasebroek), W. W. TARN, I5; The Greek Langwage (Atkinson), R. McKenzie and J. D. Denniston, I6 ; The Socratic Problem (Rogers); The Composition of Plato's A pology (Hackforth), G. C. FiELD, 17 ; Platon, Tome V (Méridier), W. L. LoRIMER, 19: The Symposium of tlato (Bury), W. L. LORIMER, 2I ; Excavations at Olynthus. V. (Robinson), A. J. B. WACE, 22 ; Plautus, Tri-

Notes on Aeschylus, Persae. II. J. C. LAwson

PAGE
1
2
4
8
9

13
14
14
14

nummus (Brix-Niemeyer-Conrad), W. BEARE, 23; An Economic Survey of Ancient Rome. I. (Frank), J. Wighr Dofr, 24; Studies of Catullus (Friess, Kapnukajas, Hezel, van Gelder), A. M. DUFF, 25 ; Plutarchi Vitae, II. i (Ziegler) ; Plut. Moralia, III (Paton etc.); Plutarch's Moralia, III (Babbitt), E. HARRIson, 26 ; Rutilius Namatianus sur son retour (Vessereau-Préchac), M. Plarnader, 27; Sidonius Apollinaris and His Age (Stevens), W. H. Semple, 29 ; Medieval and Renascence Latin, S. Gaseler, 30; Lateinisches etymologisches Wörterbuch. 5, 6 (Walde-Hofmann), P. S. NoBLe, 3I ; A Smaller Latin-English Dictionary (Smith and Lockwood), W. C. Sommers, 32 ; Some class-books, H. LISTER .

Short reviews

Summaries of periodicals

Books received

No. 2.

Notes and news

Ennius in Pers. VI. 9. A. E. HousMan

Horace Epistles I. II. 31. A. Y. CAMPBeLL Aristotle Politics II 94. J. E. Powell

Diprax 'Mrs. Malaprop.' W. M. Lindsay : Corrigendum

Reviews :

Der homerische Apolionhymnos (Jacoby); Die archaische Mythenerzählung (Dornseiff), C. M. Bowra, 60; Stasimon (Kranz), G. Morray, 62 ; De Poetica Vocabulorum Abusione apud A eschyIum (Schuursma), A. S. OWEN, 63; Election by Lot at Athens (Headlam), A. W. Gomme, 64 ; Platon, Phèdre (Robin), D. Tarrant, 64; Athenian Tribal Cycles in the Hellenistic Age (Fergason), A. M. WoodWard, 65 ; Pausanias, Vol. III (Jones), A. M. WOODWARD, 66; Early Civilisation in Thessaly (Hansen), S. Casson, 67: Sardis: Greek and Latin Inscriptions, I (Buckler and Robinson), M. N. TOD, 68;

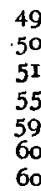

No. 3.

Platonist or Aristotelian? A. J. D. Porteous.
Campana Fragments in Florence (Beazley); Poet and Artist in Greece (Gardner) ; Attic Vasepainting (Seltman), T. B. L. WeBsTeR, 69; Pontische Vasen (Ducati), H. G. G. PAYNE, 7I; The Mediterranean in the Ancient World (Rose). H. A. ORMEROD, 72 ; Plautinische Akzentstudien (Drexler), W. BEARE, 72; Plauti Pseudolus (Sturtevant), W. BEARE, 74 ; Lucretius in English Verse (Way); Verse Translations from Lucrotius (Foxley). C. BAILEY, 75 ; Ottaviano Capoparte (Levi), R. SYme, 76 ; Le Haut-Empire (Homo), A. F. Giles, 78 ; Senecastudien (Axelson), W. C. Sommers, 79 ; Plinius Minor: Opera (Schuster), J. D. DUFF, 80; The Roman Way (Hamilton), A. M. DoFF, 8I ; Lautgesetz und Analogie (Hermann), J. FrASER, 82; England und die Antike, E. HARRISON

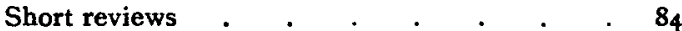

Summaries of periodicals . . . . . . 9 I

Books received . . . . $\quad$. $\quad . \quad$. 94

97 Ovid: some aspects of his character and aims. T.F. HIGHAM . . . . . . 105 
Notes and news

'Ovopa and $\pi \rho \hat{a} \gamma \mu \alpha$ in Euripides' Helen. F. SOLMSEN .

The panpipe of Daphnis. A. S. F. Gow The date of the Casina. W. BEARE

Clarus Aquilo. W. F. J. KNIGHT

Tacitus, Annals, IV, i6, 2. E. C. Woodcock

Two notes on Sappho. C. M. Bowra

Two notes. H. J. Rose

Horace, C. IV. 2. $57 \mathrm{ff.}$ M. T. TAтham

Reviews :

The Iliad of Homer rendered in English Hexameters (Murison), E. S. Forster, I27 ; Greek Tragedy: Emendations etc. I (Harry), A. S. OWEN, 128 ; Herodots Kroisos-Logos (Hellmann), C. HIGNETr, I29; Untersuchungen zur Philosophie des Eudoxos von Knidos (Karpp); Die Entstehung der aristotelischen Lehrschriften (Gohlke), D. J. Allan, I30 ; Demostene : L'Orazione per la Corona (Treves), A. W. PickardCAMBridge, 131 ; Excavations at Olynthus.

Virgil's Golden Age : Sixth Aeneid and Fourth Eclogue. H. MATtingLY

Notes on Pindar. W. A. Stone

Thucydides VIII. 5. v. R. H. DUNDAS

Proskynesis. G. C. Richards

AIӨPHTENETH $\Sigma$ BOPEH 2 . H. J. Rose

The Eumenides and the Oedipus Tyrannus. M. E Hirst

Lectio difficilior. "W. L. LORIMER : •

Reviews :

The Cretan Labyrinth (Myres), M. P. NiLsson,

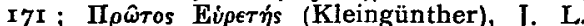
MYRES, 173; Griechische Religiosität (Nestle), H. J. Rose, I74; The Jealousy of the Gods and Criminal Law at Athens. II. (Ranulf), A. W. Gomme, I74 ; Paideia (Jaeger), T. B. L. WEBSTER, I76; Geschichte der griechischen Literatur. I 2 (Schmid), T. A. Sinclair, I77; Griechische Grammatik, 1. Lieferung (Schwyzer), R. McKenzIE, I79; The Laws of Plato (Taylor), R. G. BסRY, I8a ; Le Dis-

Notes and news

The authorship of the 'Leucippides' papyrus. J. A. Davison

Note on Plato Charmides i53B. K. 'W. LockHURST

Three notes on Aristotle. R. HAckforth

Note on a decree from Mylasa. A. Wilhelm

Two notes on Cicero, De Senectute. W. S. MaguinNess

Notes on Lewis and Short. 'R. $\dot{L}$. DúnBabin . Xenophon, Hellenica I. vI. 32. R. QUIRK .

Aristotle, N.E. I. vi. I, Iog6a I4. H. Rackham $A$ papyrus codex and an early example of 'quaiternio.' A. SodrrR

Reviews :

Staaten, Völker, Männer, aus der Geschichte des Altertums (Kornemann), A. F. GiLrs, 215 Corpus Vasorum Antiquorum. Yougoslavie, Fasc. I (Hoffiller), W. A. Hedrtley, 2I6; $A$ Handbook of Greek Literature (Rose); Griechische Literaturgeschichte, 2. Bd. (Geffcken), T. A. Sinclair, 217; Die Theogonie des Hesiodos (Schwenn), H. J. Rose, 2r9; Untersuchungen zur Sprache der euripideischen Lyrik (Breitenbach), J. D. Denniston, 220; Greek Particles
No. 4.
PAGR

17

I Ig

121

123

124

125

I 26

126

127

205
205
207
208
210
211
212
214
214
214

214
VII (Robinson), A. J. B. WACE, 132 ; Ancient Italy and Modern Religion (Conway), H. J Rose, I33; Die Kultur der Ciceronischen Zeit. II (Kroll), J. Wight DUFF, r34; Ciceronis (Yon), G. B. A. Fletcher, 135; The elegies of Propertius (Butler and Barber), A. E. HoosMAN, I36; Conversion (Nock), W. R. HALLIDAY, 139; Proclus: The Elements of Theology (Dodds). A. D. Nock, I40; Papyrusfunde und Papyrusforschung (Preisendanz), A. S. HoNT, I4I ; Excavations at Minturnae. II (Johnson), J. G. C. Anderson, 142; Zur Geschichte des Cursus Publicus (Holmberg), ]. G. C. ANDERson, 143 ; The Augustan Principate (Hammond), M. P. Charlesworth, I44; Some classbooks, R. McEwaN .

Short reviews

Summaries of periodicals

Correspondence

Books received scripta (Reis etc.); Cicéron: Traité du Destin

cours d'Hypéride contre Demosthène (Colin). A. W. Pickard-Cambridge, I8I; The Epigrams of Callimachus (Young), E. S. Forster, I82; Der Peripatetiker Ariston von Keos bei Philodem (Knögel), J. L. Srocks, 183; The PraeItalic Dialects of Italy (Conway, Johnson, and Whatmough), J. Fraser, I83; Twelve Centuries of Rome (Baker), H. Matringly, 185 ; Plaute Comédies. I, II (Ernout), W. Brare, I85; Die Komposition von Terenz' Adelphen und Plautus' Rudens (Drexler), I. D. Craig, I86; Martial, Épigrammes, Livres VIII-XIV (Izaac), A. E Hodsman, I87; Codices Latini Antiquiores. I (Lowe), E. H. Minvs, I89; Translations from the Classics into English from Caxton to Chapman (Lathrop), E. S. Forster

Short reviews

Summaries of periodicals . . . . 201

Correspondence . . . . . . . . 203

Books received.

(Denniston), W. L. Lorimer, 22I : Aristoteles IIEPI IIOIHTIKH 2 (Gudeman), C. G. HARDIE, 223; C. Lucilii Saturarum Reliquiae (Terzaghi), C. J. Fordyce, 225; T. Lucreti Cari de Rerum Natura (Martin), L, H. G. Greenwood, 226; La Rivolta di Catilina (Amato), M. CARY, 227 ; The Priapea and Ovid (Thomason), J. Wight Dofp, 227 ; Vitruvius on Architecture, II (Granger), D. S. ROBERTSON, 228; Untersuchungen $z \boldsymbol{z u}$ Senecas dramatischer Technik (Friedrich), W. F. J. KNIGHT, 229; Studien $z u$ den Annalen des Tacitus (Eriksson), E. C. Marchant, 230; Ptolemaios und Porphyrios über die Musik (Düring), J. F. MoonTFORD, 231 ; Claudien: Etudes sur sa Poésie et son Temps and Invectives contre Eutrope (Fargues); Claudian: The Rape of Proserpine in English Verse (Pope), W. H. SRMPLE, 232 ; Select Letters of St. Jevome, with an English transiation (Wright), A. Sooter, 233 ; $A$ History of Secular Latin Poetry in the Middle Ages (Raby), J. Wight DUFF.

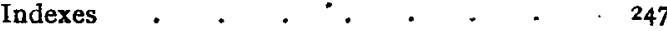

